\title{
Priprave na predsedovanje Slovenije Evropski uniji
}

\author{
UDK: 341.22/24EU \\ Marija Minka Jerebič \\ Ministrstvo za kulturo Republike Slovenije \\ minka.jerebic@gov.si
}

\section{IZVLEČEK}

Decembra 2004, ko je zasedal Svet Evropske unije, je bilo odločeno, da bo Republika Slovenija prva med novimi državami članicami, ki bo prevzela predsedovanje Evropski uniji.

Za Slovenijo je to velik izziv, dolžnost in odgovornost, kajti predsedovanje Svetu Evropske unije in Evropskemu svetu ni samo projekt na področju evropskih zadev, temveč je to projekt, ki je nacionalnega pomena. Predsedovanje ni priložnost za predsedujočo državo, da v ospredje postavi svoje specifične nacionalne interese, saj bi tako izgubila kredibilnost. To je projekt, ki zahteva sodelovanje velikega števila ljudi. Uspešno predsedovanje pa naj $v$ ospredje postavlja evropske interese. Zaradi tega so priprave na predsedovanje izrednega pomena.

Prispevek obravnava priprave na predsedovanje, vsebine posameznih projektov, naloge, ki si jih je zadala država, da jih bo uresničila $v$ času predsedovanja. $v$ zadnjem delu pa so predstavljeni rezultati ankete, ki je bila izvedena med državljani Slovenije o poznavanju priprav na predsedovanje.

Ključne besede: predsedovanje Evropski uniji, priprave na predsedovanje, poročilo o pripravah, program predsedovanja

\section{Uvod}

Predsedovanje držav članic Evropske unije Svetu Evropske unije je vpeljala že Pogodba o ustanovitvi Evropske gospodarske skupnosti, t. i. Rimska pogodba iz leta 1957. Ta je določila, da države članice izmenoma prevzamejo funkcijo predsednika Sveta ministrov za dobo šestih mesecev. Z Maastrichtsko pogodbo leta 1992 so se funkcije predsedstva razširile tudi na predsedovanje Evropskemu svetu, ki se pod predsedstvom voditelja predsedujoče države ali vlade države članice sestane vsaj dvakrat na leto (Lenarčič, 2006, str. 3). 
Marija Minka Jerebič

Priprave na predsedovanje Slovenije Evropski uniji

Če bi Pogodba o Ustavi za Evropo vstopila v veljavo, bi vidnejšo spremembo pomenila prav zamenjava šestmesečnega samostojnega predsedovanja s t. i. "skupinskim 18-mesečnim predsedovanjem". Kljub temu, da evropska ustavna pogodba še ne velja, so države članice izrazile željo po okrepljenem sodelovanju med tremi zaporednimi polletnimi predsedstvi.

Predsedovanje Evropski uniji v prvi polovici leta 2008 je za Slovenijo velik izziv, saj bo med novimi državami članicami prva, ki bo opravljala to funkcijo (Lenarčič, 2006, str. 3). Prevzem predsedovanja Evropski uniji je za državo, ki je pred tremi leti pristopila $\mathrm{k}$ uniji, izjemno zahteven nacionalni projekt.

Vlada Republike Slovenije je začela priprave na predsedovanje takoj po odločitvi Sveta Evropske unije.

Za uspešno predsedovanje je še posebej pomembno upoštevati načeli nevtralnosti in nepristranskosti. Cilj predsedovanja je namreč doseči napredek pri delu unije. Temu je prilagojen tudi način dela, ki ga zaznamujejo predvsem iskanje kompromisnih rešitev med sedemindvajsetimi državami članicami ob hkratnem upoštevanju stališč Evropske komisije in Evropskega parlamenta (http://svez.gov.si).

Za uspešno izvedbo predsedovanja, ki pomeni izjemno povečan obseg dela $\vee$ predsedujoči državi in njenem stalnem predstavništvu $\vee$ Bruslju, mora država pripraviti in usposobiti svojo celotno upravo. Pri tem prilagodi metode dela svoji tradiciji in kulturi, način organiziranja in delovanja pa je odvisen tudi od velikosti države in njenih interesov. Pri predsedovanju predsedujoči državi nudi pomoč Generalni sekretariat Sveta Evropske unije (Bagon, 2006, str. 1). Vsekakor pa to ni dovolj. V proračunu je treba zagotoviti finančna sredstva, uspešno usposobiti ljudi, ki bodo sodelovali pri teh projektih, zagotoviti ustrezne protokolarne objekte, pripraviti logistiko ter zagotoviti dober program, ki ga bo država favorizirala $v$ času predsedovanja.

\subsection{Organizacijska struktura za priprave in izvedbo predsedovanja}

Vlada Republike Slovenije je 6. januarja 2005 s posebnim sklepom ustanovila ožjo delovno skupino za priprave na predsedovanje. Zagotavljala naj bi konsistentno vodenje projekta slovenskega predsedovanja uniji, oblikovala splošne politične smernice in prioritete ter nadzorovala potek priprav na predsedovanje $v$ okviru državne uprave (Lenarčič, 2005, str. 3).

Za operativno vodenje priprav in izvedbo projekta predsedovanja ter za koordinacijo, usmeritve in nadzor dela vseh sodelujočih pri projektu predsedovanja 
je ožja delovna skupina imenovala širšo delovno skupino za predsedovanje. To skupino vodi državni sekretar za evropske zadeve, sestavljajo pa jo še predstavniki posameznih ministrstev in drugih organov. Delovna skupina koordinira, usmerja in nadzira delo posameznih podskupin, ministrstev in drugih organov, ki so vključeni v pripravo predsedovanja (Lenarčič, 2005, str. 3).

$\checkmark$ podporo širši delovni skupini je bila oblikovana posebna Projektna skupina za koordinacijo priprav in predsedovanje Slovenije Evropski uniji v Službi vlade Republike Slovenije za evropske zadeve. Ustanovljena je bila tako za podporo predsedovanja in priprave nanj, kot tudi za kontaktno točko Slovenije za komuniciranje s sopredsedujočima državama, Nemčijo in Portugalsko (Lenarčič, 2005, str. 3).

Ožja delovna skupina je na svoji prvi seji predstavila pet osnovnih nalog, ki jih je treba izvesti $\vee$ okviru priprav na predsedovanje. Za izvedbo posameznih nalog je znotraj širše delovne skupine oblikovala pet podskupin: podskupino za program predsedovanja, podskupino za kadre, podskupino za komunikacijo z javnostmi in promocijo, podskupino za logistično organizacijo predsedovanja in podskupino za proračun predsedovanja (Lenarčič, 2005, str. 3).

Ministrstva, vladne službe, uradi in drugi organi se vključujejo $v$ delo vseh podskupin in tako zagotavljajo, da priprave potekajo nemoteno. Dobro pripravljena država $\vee$ času predsedovanja tako ne bo imela težav.

\subsection{Potek priprav na predsedovanje Slovenije Evropski uniji}

Organizacijske priprave na predsedovanje Slovenije Evropski uniji so stekle takoj po tem, ko je bil v ožji delovni skupini sprejet koncept priprav. Projektna skupina za koordinacijo priprav in predsedovanje je opredelila osnovne elemente projektnih nalog podskupin na posameznih področjih in okviren terminski načrt za izvedbo posameznih nalog (Lenarčič, 2005, str. 5).

$\mathrm{K}$ vodenju tako kompleksnega procesa kot so priprave in izvedba predsedovanja, je treba pristopiti projektno. Zato je bilo določeno, da morajo biti $v$ projektnih nalogah, ki jih bodo pripravile podskupine, podrobneje opredeljene vse identificirane naloge, metode dela, nosilci nalog, potrebni kadri in roki (Lenarčič, 2005, str. 5). Vsi, ki so vključeni v projekt, morajo imeti vodilo in enotno predstavo o tem, katere naloge je treba opraviti, kako, kdo jih bo opravil in kdaj.

Delo v podskupinah koordinira, usklajuje in usmerja državni sekretar za evropske zadeve in vodja širše delovne skupine, ki $v$ ta namen sklicuje sestanke $z$ 
Marija Minka Jerebič

\section{Priprave na predsedovanje Slovenije Evropski uniji}

vodji podskupin, po potrebi pa tudi s predstavniki državnih organov (Lenarčič, 2005, str. 5).

Prvi osnutki projektnih nalog so bili pripravljeni v začetku aprila 2005. Kasneje so bili nadgrajeni $v$ skladu z usmeritvami ožje delovne skupine ter z dogovori na usklajevalnih sestankih vodij podskupin in sestankih med podskupinami in projektno skupino (Lenarčič, 2005, str. 6). Poleg tega so bili upoštevani tudi predlogi Stalnega predstavništva Republike Slovenije pri Evropski uniji v Bruslju in drugi predlogi, informacije in znanja, pridobljena na delovnih sestankih $\vee$ zvezi s predsedovanjem na Generalnem sekretariatu Sveta Evropske unije ter na obiskih pri koordinatorjih in organizatorjih predsedovanja $\vee$ drugih državah.

Končni popravki in dopolnitve projektnih nalog so bili opravljeni po obravnavi $\vee$ ožji delovni skupini. Po sprejetju gradiva na vladi je bila zaključena prva faza priprav države na predsedovanje (Lenarčič, 2005, str. 6). Hkrati se je začelo intenzivno delo na posameznih področjih projektnih nalog in usklajevanjem med podskupinami. Nekatere naloge se že izvajajo.

Državni sekretar za evropske zadeve je problematiko priprav obravnaval na sestankih delovne skupine in na sestankih s posameznimi ministri ter direktorji vladnih služb in drugih organov. Ministrstvom so bili posredovani osnutki projektnih nalog, informacije o izvajanju priprav in o samem predsedovanju (Lenarčič, 2005, str. 6).

$\checkmark$ aprilu 2006 je bilo pripravljeno poročilo o pripravah na predsedovanje Slovenije Evropski uniji v prvi polovici leta 2008, ki je bilo posredovano Državnemu zboru (Lenarčič, 2006, str. 3). To pa ni bilo edino poročilo. Konec leta 2006 so vsa tri predsedstva (Nemčija, Portugalska in Slovenija) predstavila skupni program. Zunanji minister Nemčije je predstavil ustavni proces, evropsko sosedsko politiko in energetiko. Portugalski zunanji minister pa je predstavil Lizbonsko strategijo - krepitev zaposlovanja in gospodarske rasti. Predstavljeni so bili tudi širitev, Zahodni Balkan in medkulturni dialog. Prihodnja tri predsedstva si bodo prizadevala za nadaljnjo širitev schengenskega in evro območja.

Slovenija namerava posebno pozornost posvetiti medkulturnemu dialogu, ki se bo odvijal predvsem $v$ okviru razlik in podobnosti med krščanstvom in islamom. Z uvrstitvijo medkulturnega dialoga med prioritete slovenskega predsedovanja želi Slovenija prispevati k razmisleku o identiteti Evrope in h krepitvi evropske zavesti ter pripadnosti skupnemu civilizacijskemu prostoru. Z razširitvijo dimenzije dialoga izven unije, $v$ povezavi $z$ drugimi prioritetami predsedovanja, Slovenija ponuja komunikacijski forum državam Balkana.

$\checkmark$ letu 2006 so priprave prešle $v$ izvedbeno fazo. Na področju programa so bile $v$ tem letu izpostavljene štiri teme, za katere vlada meni, da bi lahko bile $v$ 
letu 2008 za Evropsko unijo strateškega pomena. Izbor prioritetnih nalog se lahko spremeni. Vlada Republike Slovenije bo o prioritetah dokončno odločala šele konec leta 2007.

\subsection{Vsebina projektnih nalog za predsedovanje}

$\checkmark$ projektnih nalogah za posamezna področja priprav na predsedovanje so podskupine natančno opredelile naloge s svojega področja, nosilce za njihovo izvedbo in določile roke, $v$ katerih morajo biti naloge opravljene ter pripravile preliminarno oceno o potrebnih kadrovskih virih in stroških (Lenarčič, 2005, str. 6).

Podskupine so projektne naloge sproti dopolnjevale z novimi informacijami in nalogami ter podrobnejšimi opredelitvami že zastavljenih nalog (Lenarčič, 2005, str. 6).

Projektna skupina pri državnem sekretarju za evropske zadeve na podlagi poročil in gradiv spremlja izvajanje priprav. Državni sekretar za evropske zadeve pa o pripravah na predsedovanje poroča ožji delovni skupini in dvakrat letno Vladi Republike Slovenije (Lenarčič, 2005, str. 6). To je izrednega pomena, saj tako vlada lahko ves čas priprav obvešča parlament o izvajanju projekta. Parlament pa lahko brez težav potrdi delo vlade in odločitve $\vee$ zvezi s sprejetjem posameznih nalog. $\vee$ projekt predsedovanja bo vključenih več kot 1000 visoko usposobljenih strokovnjakov. Celotna ekipa ljudi, ki bo odgovorna za izvedbo predsedovanja, je bila oblikovana $\vee$ začetku leta 2006, nekateri so z delom pri projektu že začeli, drugi pa se še intenzivno usposabljajo. $V$ času predsedovanja bo $\vee$ Sloveniji organiziranih predvidoma več kot 100 neuradnih dogodkov. Logistične priprave za izvedbo teh dogodkov so že v polnem teku.

\subsection{Naloge predsedujoče države in splošna načela predsedovanja}

Slovensko predsedovanje se začne 1. januarja 2008 in konča 30. junija 2008. V tem obdobju bo Slovenija prevzela tri pomembne skupine nalog:

1. vodila bo delo vseh sestav Sveta Evropske unije in sestav Evropskega sveta,

2. zastopala bo Svet Evropske unije v odnosu do drugih institucij Evropske unije in

3. zastopala bo Evropsko unijo v mednarodni skupnosti (Lenarčič, 2006, str. 1). 


\section{Priprave na predsedovanje Slovenije Evropski uniji}

K 1: Pravni okvir predsedovanja sta Pogodba o ustanovitvi Evropske skupnosti in Pogodba o Evropski uniji, ki pa funkcij predsedstva ne opredeljujeta podrobneje. Te so določene $v$ Poslovniku Sveta, predvsem s členi 1, 2, 11, 19, 20 in 26 (Ur. I. Evropske unije, 92/C 224/01, 1992).

Predsedstvo med drugim pripravlja, sklicuje in vodi sestanke Sveta Evropske unije na vseh ravneh. Predsedujoči delovnim telesom Sveta Evropske unije je odgovoren, da dela na zasedanjih potekajo gladko, saj je učinkovito in ustvarjalno vodenje sestanka s 27. delegacijami držav članic in delegacijo Evropske komisije zelo zahtevna naloga, posebno še ob upoštevanju postopkovnih pravil in nekaterih dodatnih omejitev (Lenarčič, 2006, str. 2).

Po dosedanjih izkušnjah predsedujoča država $v$ šestmesečnem mandatu predseduje dvema zasedanjema Evropskega sveta, okoli 40 ministrskim zasedanjem, 60 zasedanjem Odbora stalnih predstavnikov (COREPER I in II) ter približno 3.000 zasedanjem delovnih skupin in različnih odborov. Poleg priprave in vodenja velikega števila formalnih zasedanj mora predsedujoča država opraviti tudi veliko neuradnega dela $v$ obliki lobiranj, pogajanj in neformalnih sestankov s posameznimi državami članicami, skupinami držav ter evropskimi institucijami (Lenarčič, 2006, str. 3).

Sodelovanje predstavnikov Slovenije s predstavniki že predsedujočih držav potekajo zelo intenzivno, saj si s tem pridobivajo izkušnje drugih držav in tudi spremljajo programe, ki so jih imele posamezne države $\vee$ času predsedovanja.

Poleg uradnega dela predsedovanja, ki se odvija na sestankih $\vee$ Bruslju, Luksemburgu in Strasbourgu, se je uveljavila tudi praksa priprave neuradnih srečanj $\vee$ predsedujoči državi. $\vee$ nasprotju $s$ formalnimi sestanki na sedežu evropskih institucij, ki jih skoraj v celoti logistično organizira in financira Generalni sekretariat Sveta Evropske unije, sta organizacija in financiranje dogodkov v predsedujoči državi njeno breme (Lenarčič, 2006, str. 4).

K 2: Predsedujoči Svetu Evropske unije predstavlja Svet Evropske unije v stikih z drugimi institucijami unije. Posebnega pomena je sodelovanje z Evropskim parlamentom in Evropsko komisijo. $V$ tem mora predsedujoča država predstavljati stališče Sveta Evropske unije $v$ t. i. trialogu z omenjenima evropskima institucijama, največkrat na področju zadev, povezanih s proračunom unije, ter splošnih in proceduralnih zadev (Lenarčič, 2006, str. 4).

Sodelovanje z Evropskim parlamentom je zelo obsežno in zahtevno. Ob začetku in ob koncu predsedstva predsednik vlade predsedujoče države na plenarnem zasedanju Evropskega parlamenta predstavi program predsedstva 
ter zaključno poročilo, pred parlamentom pa nastopi tudi po zasedanjih Evropskega sveta. Ministri predsedujoče države $\vee$ času predsedstva nastopajo pred odbori Evropskega parlamenta. Dobri odnosi z Evropskim parlamentom so pomembni, ker je ta $v$ vedno večjem deležu evropskih aktov sozakonodajalec. $\checkmark$ zakonodajnih postopkih soodločanja Svet Evropske unije $v$ pogajanjih z Evropskim parlamentom zastopa predsedujoča država. Ker je Evropski parlament politična institucija, je ključnega pomena dobro sodelovanje z njim na politični ravni (Lenarčič, 2006, str. 4).

Evropska komisija ima na področjih prvega stebra Evropske unije izključno iniciativno zakonodajno pravico, zato je dnevni red dela Sveta Evropske unije v veliki meri odvisen od dinamike njenega dela. Komisija ima tudi veliko strokovnega znanja, zato so dobri odnosi z njo in njenimi službami potrebni za uspešno vodenje predsedovanja (Lenarčič, 2006, str. 4).

K 3: Z Maastrichtsko pogodbo je predsedstvo pridobilo tudi pristojnosti na področju skupne zunanje in varnostne politike. Predsedstvo $v$ teh zadevah zastopa Evropsko unijo in je odgovorno za izvajanje odločitev, sprejetih skladno $s$ tem naslovom. $V$ tej funkciji izraža tudi stališča unije $v$ mednarodnih organizacijah in na mednarodnih konferencah. Predsedstvo je tako odgovorno za t. i. politični dialog z državami, mednarodnimi organizacijami ter regionalnimi skupinami (Lenarčič, 2006, str. 4).

Predsedujoča država ima pri tej nalogi veliko politično odgovornost in obveznost, predvsem predsednik vlade in zunanji minister kot tudi drugi ministri. Nastopati morajo $v$ imenu vseh držav članic in zastopati skupne interese na mednarodnem področju. Predsedujoča država sodeluje tudi z visokim predstavnikom za skupno zunanjo in varnostno politiko in komisarjem, pristojnim za zunanje odnose in evropsko sosedsko politiko (Lenarčič, 2006, str. 4).

\subsection{Vsebinske priprave na predsedovanje}

$\checkmark$ teku je oblikovanje vsebinskih prioritet predsedovanja ter tem, za katere se glede na t. i. podedovano agendo lahko predvideva, da bodo aktualne $v$ času slovenskega predsedovanja.

V okviru širših prioritet predsedovanja je ožja delovna skupina ocenila, da bi bilo, zaradi strateškega pomena za Evropsko unijo in Slovenijo smiselno posebej izpostaviti štiri teme:

- prihodnost Evropske unije in institucionalni razvoj,

- Širitev Evropske unije in Zahodni Balkan ter nova sosedska politika, 
Marija Minka Jerebič

Priprave na predsedovanje Slovenije Evropski uniji

- energetika in

- $\quad$ medkulturni dialog (Lenarčič, 2006, str. od 8 do 10).

Ob spremenjenih političnih usmeritvah Evropske unije ali drugačnem uresničevanju sprejemanja zakonodaje se lahko te prednostne naloge do 2008 še spremenijo. Izbor prioritet bo tako svojo končno podobo dobil šele nekaj mesecev pred dejanskim nastopom predsedovanja.

\section{Sodelovanje}

Priprave na predsedovanje potekajo tudi $\vee$ okviru mednarodnih bilateralnih in drugih srečanj z izmenjavo mnenj ter izkušenj. Zlasti pomembni so bili stiki z Nemčijo in s Portugalsko ter z nekaterimi drugimi državami tako znotraj kot tudi zunaj območja Evropske unije.

\subsection{Sodelovanje z Nemčijo in s Portugalsko ter Francijo}

V letu 2006 je bil spremenjen poslovnik Sveta Evropske unije, ki sedaj določa oblikovanje 18-mesečnega programa predsedovanja. Prvi takšen program se je začel izvajati s predsedovanjem Nemčije v letošnjem letu. Slovenija, ki predseduje za Nemčijo in Portugalsko, je tako z omenjenima državama pripravila skupni 18-mesečni program treh predsedstev. Osnutek usklajenega programa je moral biti pripravljen že $v$ juniju 2006, zato je $v$ drugi polovici lanskega leta potekalo veliko sestankov med generalnimi direktorji držav članic, ki so zadolženi za priprave na predsedovanje. Po intenzivnih pripravah in izdelavi osnutka programov so se pogovori nadaljevali na ravni namestnikov zunanjih ministrov, proti koncu leta 2006 pa na ravni zunanjih ministrov (Lenarčič, 2006, str. 11). Osrednji namen uvedbe 18-mesečnega skupinskega predsedovanja je bil okrepiti sodelovanje in tako prispevati k dolgoročnemu usklajenemu razvoju strateških politik Evropske unije.

Skupni program predsedovanja deloma vpliva tudi na koledar, ki ga morajo Nemčija, Portugalska in Slovenija uskladiti v delu, ki se nanaša na srečanja $s$ tretjimi državami (Lenarčič, 2006, str. 11). Ker vse tri države želijo oblikovati skladen razvoj osrednjih politik unije, sodelujejo tudi na druge načine, čeprav $k$ temu nobena od treh držav ni formalnopravno zavezana. 
Slovenija je začela sodelovati tudi s Francijo, ki bo Svetu Evropske unije predsedovala za njo kot prva v skupini naslednjih treh predsedujočih držav. Cilj teh pogovorov je predvsem zagotoviti skladen vsebinski prehod iz enega predsedovanja $v$ drugega $z$ namenom omogočiti neprekinjen razvoj ključnih strateških politik unije v letu 2008 (Lenarčič, 2006, str. 11).

\subsection{Sodelovanje z Evropskim parlamentom in Evropsko komisijo ter Državnim zborom Republike Slovenije}

Glede na povečevanje vloge Evropskega parlamenta in glede vloge $\vee$ postopkih sprejemanja pravnih aktov je pomembno, da predsedujoča država z njim dobro sodeluje (Lenarčič, 2006, str. 11).

Dobro sodelovanje je potrebno tudi z Evropsko komisijo, saj ima kot edina evropska institucija pristojnost zakonodajne pobude na območju Evropske skupnosti. Tako je $\vee$ največjem interesu predsedujoče države, da Evropsko komisijo pravočasno seznani s strateškimi prioritetami, ki jih komisija lahko upošteva pri oblikovanju svojih zakonodajnih predlogov (Lenarčič, 2006, str. 11). Slovenija ima z obema institucijama že navezane stike na najvišji ravni.

Program predsedovanja sestavljajo trije deli: strateški del, specifične prioritete in celoviti program predsedovanja.

$\checkmark$ strateškem delu 18-mesečnega programa je zastavljen okvir delovanja Evropske unije na najpomembnejših področjih, kot so nadaljnji razvoj unije, naslednji koraki glede njene prihodnosti, širitev, krepitev odnosov unije z državami na vzhodu in jugu unije, posebno prek mehanizma Evropske sosedske politike. $\vee$ ta del spadata tudi širitev schengenskega in evra območja ter zagotavljanje ekonomske dinamike in rasti.

Specifične prioritete programa zajemajo Pogodbo o Ustavi za Evropo, prihodnjo širitev, migracijsko politiko, učinkovito varovanje zunanjih meja unije, policijsko in sodno sodelovanje, razvoj evropskega območja miru in stabilnosti, zagotavljanje evropske prihodnosti držav Zahodnega Balkana in krepitev odnosov z državami evropske soseščine. Celoviti program zajema zadeve, ki bodo predvidoma obravnavane $v$ prihodnjih 18 mesecih.

$\mathrm{Na}$ podlagi skupnega 18-mesečnega programa bo Slovenija $v$ drugi polovici leta 2007 oblikovala podrobnejši šestmesečni program predsedovanja, ki bo bolj konkretno odražal predvidene prioritete slovenskega predsedovanja.

Dobro sodelovanje je izrednega pomena tudi med Vlado Republike Slovenije in Državnim zborom, ne le $\vee$ času priprav, pač pa tudi $\vee$ času predsedovanja. 
Marija Minka Jerebič

Priprave na predsedovanje Slovenije Evropski uniji

Stalno predstavništvo Republike Slovenije pri Evropski uniji je $v$ lanskem letu izvedlo na področju predsedovanja celo vrsto dejavnosti $\vee$ podporo pripravam na predsedovanje $\vee$ nacionalni prestolnici. Veliko dela je bilo opravljenega prav pri oblikovanju 18-mesečnega programa $v$ sodelovanju $z$ generalnim sekretariatom Sveta Evropske unije, s pridobivanjem informacij o izkušnjah drugih predsedujočih držav ter z navezovanjem stikov z institucijami Evropske unije.

\section{Informiranost slovenske javnosti o pripravah na predsedovanje}

Priprave na predsedovanje Slovenije Evropski uniji so $v$ polnem teku. Državni organi izvršujejo naloge, ki jih pokriva njihovo področje dela. Kako so o pripravah na predsedovanje obveščeni državljani Republike Slovenije, ugotavljamo iz ankete, ki je bila izvedena na območju celotne države.

\subsection{Raziskovalni pristop}

Anketiranci so bili povabljeni k anketnemu sodelovanju po telefonu. Po privolitvi k sodelovanju so se odločili, kako bodo anketo izpolnjevali. Možnosti anketiranja so bile osebno anketiranje, internetno anketiranje in anketa po pošti. Pri poštnem anketiranju se je veliko anketirancev odločilo, da so izpolnjeno anketo poslali po telefaksu.

Vzorec je bil oblikovan s postopkom naključnega izbora gospodinjstev, kjer je bila upoštevana prostorska razpršenost glede na slovenske statistične regije. Kriterij izbora sogovornika $\vee$ gospodinjstvu je bil: polnoletna oseba, državljan Republike Slovenije z volilno pravico, ki je zadnji praznoval rojstni dan. Končni vzorec znaša 152 anketirancev, vzorec je reprezentativen s spolom, starostno skupino in statusom ter statističnimi regijami. Anketiranje je trajalo od 30. decembra 2006 do vključno 23. januarja 2007.

\subsection{Rezultati}

Predstavitev rezultatov je razdeljena $\vee$ naslednje tematske sklope:

- vzorec anketirancev,

- variabilni del (aktualna tematika) in

- prepoznavnost Slovenije v svetu. 


\section{Priprave na predsedovanje Slovenije Evropski uniji}

\subsubsection{Vzorec anketirancev}

Pri anketi je sodelovalo 152 anketirancev, od tega je bilo 46 odstotkov moških in 54 odstotkov žensk.

Anketo so izpolnjevale osebe, ki so bile polnoletne, so imele volilno pravico in so bili državljani Republike Slovenije. 33 odstotkov anketirancev je bilo uvrščenih $v$ starostno skupino od 36 let do 45 let. Naslednji starostni skupini, ki sta močno zastopani, sta starostna skupina anketirancev od 26. leta do 35. leta in od 46 . leta do 55. leta. Zastopanost se giblje od $22 \%$ do $25 \%$.

Vprašanje po statusu se je nanašalo na status, ki ga imajo anketiranci (dijak, študent; zaposlen; nezaposlen; upokojenec). Med anketiranci je bilo največ zaposlenih, to je kar 86 odstotkov. Na drugem mestu so bili upokojenci in dijaki oziroma študentje, le štiri osebe od 152 anketirancev so bile brezposelne. Iz omenjenega vzorca razberemo, da gre za aktivno prebivalstvo, ki spremlja dogajanje $\vee$ Sloveniji po različnih medijih.

Anketiranci, ki so sodelovali $v$ anketi, so bili iz celotnega geografskega območja Slovenije, največ anketirancev je prihajalo iz Osrednjeslovenske statistične regije, sledili sta Gorenjska in Goriška regija.

Ne glede na statistično regijo so glede na spol v vseh regijah različno sodelovali moški in ženske. $V$ nekaterih regijah je sodelovalo več moških kot žensk, $v$ drugih je bilo sodelovanje obrnjeno.

Za način izpolnjevanja ankete so anketiranci sodelovali po svoji odločitvi. Osebno anketiranje je potekalo $v$ petih slovenskih mestih: Ljubljani, Mariboru, Celju, Kopru in Kranju. Drugim anketirancem je bila anketa poslana po pošti, telefaksu ali elektronski pošti. Največ je bilo poslanih in vrnjenih anket po elektronski pošti.

Velikih odstopanj med spoloma $\vee$ načinu pošiljanja ankete ni bilo, razen pri pošiljanju po telefaksu, kjer se je več žensk odločilo za takšen način pošiljanja. Glede na statistične regije pa večjega odstopanja ni bilo, saj je $v$ večini primerov prevladoval elektronski način pošiljanja, kar pomeni, da se Slovenci dobro poslužujejo sodobne informacijske tehnologije.

\subsubsection{Variabilni del}

Prvo vprašanje $v$ variabilnem delu se je nanašalo na dobo predpriprav na predsedovanje.

Slovenija se je že januarja 2005 začela pripravljati na predsedovanje, saj izkušnje kažejo, da država, ki predseduje prvič, za priprave potrebuje vsaj tri 
Marija Minka Jerebič

Priprave na predsedovanje Slovenije Evropski uniji

leta. Leta 2005 so bili postavljeni organizacijski in tehnični temelji za izvedbo projekta. Celotne priprave z vidika oblikovanja splošnih političnih smernic in prednostnih nalog na najvišji ravni pa so se začele leto kasneje.

$\checkmark$ anketi se je 60 odstotkov anketirancev opredelilo, da je za Slovenijo, ki je $\vee$ Evropski uniji novinka, dovolj dolga doba za pripravo na predsedovanje. 24 odstotkov jih je menilo, da to ni dovolj dolga doba, medtem ko jih 16 odstotkov ni vedelo o tem ničesar. Lahko sklepamo, da kljub temu, da je več kot polovica anketirancev vedela, da potekajo priprave na predsedovanje, jih 40 odstotkov to področje ni zanimalo. To prikazuje veliko nezanimanje za priprave na predsedovanje ali pa popolno zaupanje delovnim skupinam, ki se s tem ukvarjajo.

\section{Preglednica 1: Odgovori na vprašanje: Priprave na predsedovanje Slovenije Evropski uniji potekajo od leta 2005 - Ali je to dovolj dolga doba?}

N

N 50

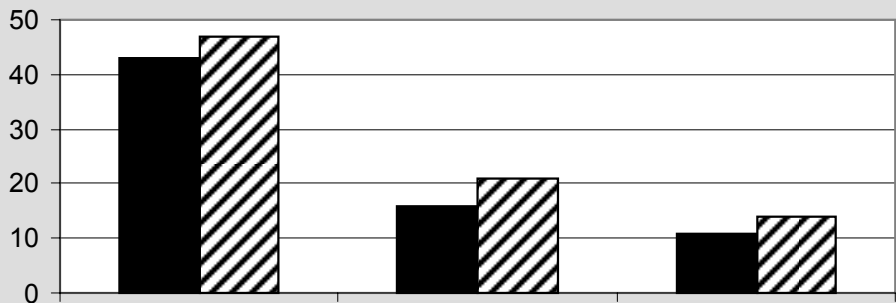

odgovori

da

ne

ne vem

- moški ם ženske

Pri podrobnejši primerjavi med spoloma, ki so ocenjevali, ali je za Slovenijo dovolj dolga doba za priprave na predsedovanje uniji, ni bilo bistvenih odstopanj, tako pri vseh treh možnih odgovorih.

Namen naslednjega zastavljenega vprašanja je bil, ali anketiranci vedo, na katerih področjih potekajo predpriprave.

Za operativno vodenje priprav in izvedbo projekta je odgovorna širša delovna skupina, ki jo sestavljajo predstavniki posameznih ministrstev in drugih organov. $\mathrm{V}$ okviru te skupine je oblikovanih pet podskupin, ki so odgovorne za pripravo in izvedbo osrednjih nalog:

- $\quad$ podskupina za program predsedovanja (vodi jo Ministrstvo za zunanje zadeve),

- $\quad$ podskupina za kadre (vodi jo Ministrstvo za javno upravo), 
- podskupina za komunikacijo z javnostmi in promocijo (vodi jo Urad Vlade Republike Slovenije za informiranje - sedaj komuniciranje),

- podskupina za logistično organizacijo predsedovanja (vodi jo Protokol Republike Slovenije) in

- $\quad$ podskupina za proračun predsedovanja (vodi jo Ministrstvo za finance).

\section{Preglednica 2: Odgovori na vprašanje: Ali so anketiranci vedeli na katerih področjih potekajo priprave na predsedovanje Slovenije EU?}

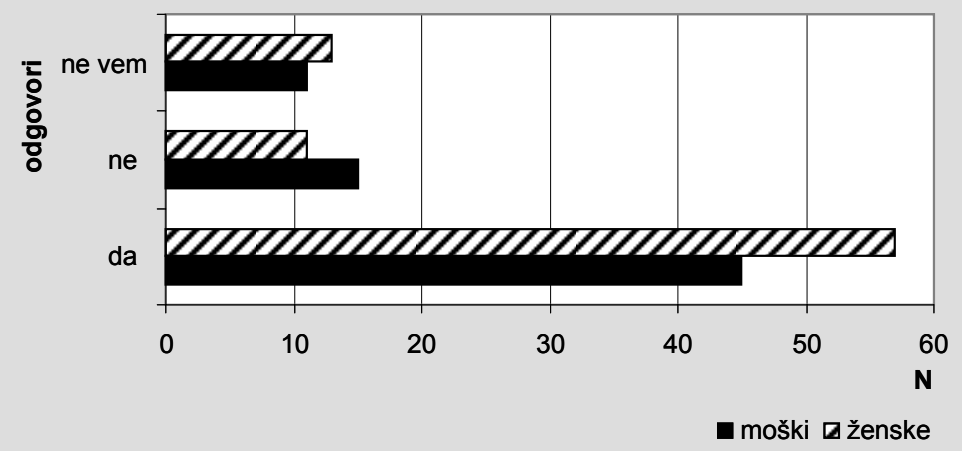

Od vseh anketirancev jih je $67 \%$ vedelo, na katerih področjih potekajo priprave na predsedovanje Slovenije Evropski uniji. Le $17 \%$ anketirancev ni poznalo področij, na katerih potekajo predpriprave, medtem ko je bilo 16 odstotkov tistih, ki o tem niso vedeli ničesar.

Narejena je bila tudi primerjava med spoloma za isto vprašanje. Zanimiva je ugotovitev, da je 56 odstotkov žensk vedelo, na katerih področjih potekajo priprave $v$ primerjavi z moškimi, ki so na to vprašanje odgovorili pozitivno in jih je bilo $44 \%$. Kar za 4 odstotne točke pa moški spol v primerjavi z ženskim ni vedel, na katerih področjih potekajo priprave. Osem odstotnih točk je bilo razlike med spoloma pri zadnjem odgovoru, kjer so obkrožili možen odgovor "ne vem".

Urad vlade za komuniciranje dobro skrbi za informiranost državljanov $\vee$ pripravah na predsedovanje. Velik delež pri tem pa imajo tudi mediji, ki poročajo o tem.

Za uspešne predpriprave na predsedovanje in samo predsedovanje je treba zagotoviti dodatna finančna sredstva. 
Marija Minka Jerebič

Priprave na predsedovanje Slovenije Evropski uniji

Preglednica 3: Odgovori na vprašanje: Slovenija je v proračunu namenila finančna sredstva za predpriprave na predsedovanje in za samo predsedovanje. Ali menite, da jih je dovolj?

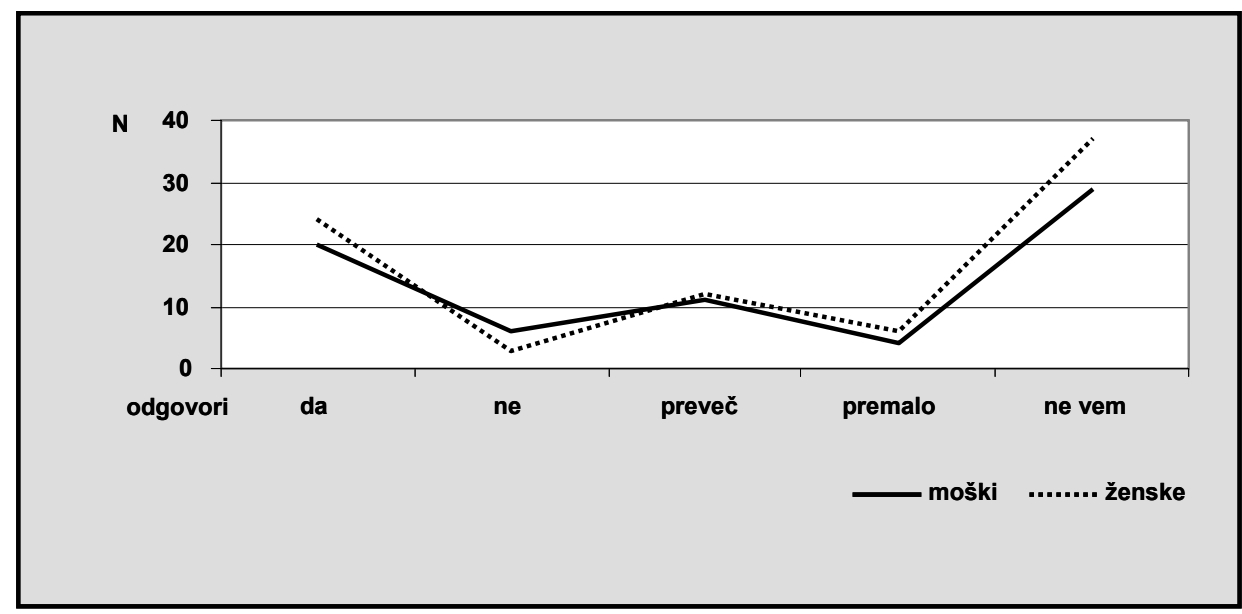

$\checkmark$ skladu s proračunskim memorandumom je za predsedovanje Slovenije Evropski uniji predvidenih 13,7 milijard SIT (57.169.087,00 EVRO). Sredstva za predsedovanje so predvidena $v$ rebalansih proračuna za leto 2005 (112,2 mio SIT - 468.202,00 EVRO) ter v sprejetih proračunih za leti 2006 (1,174 mrd SIT 4.899.015,00 EVRO) in 2007 (5,225 mrd SIT - 21.803.539,00 EVRO). Začel se je tudi že postopek načrtovanja sredstev za leto 2008 v okviru priprave proračuna za to leto (http://svez.gov.si).

Odgovor, kako je javnost obveščena o višini sredstev, ki jih je Vlada Republike Slovenije načrtovala za predpriprave na predsedovanje in samo predsedovanje, je podan $v$ naslednjem odstavku.

Od 152 anketirancev je kar 44 anketirancev odgovorilo, da je $v$ proračunu dovolj finančnih sredstev za predpriprave in za samo predsedovanje Slovenije $v$ uniji. Le 9 anketirancev se je izreklo, da finančnih sredstev ni dovolj, 23 jih je menilo, da jih je preveč, 10 ljudi se je strinjalo z ugotovitvijo, da jih je premalo in kar je zelo presenetljivo, 66 anketirancev ni vedelo o tem ničesar.

$\checkmark$ zgornjem grafu so prikazani odgovori moških in žensk. Večjih odstopanj pri možnih odgovorih sicer ni, razen pri zadnjem, kjer kar 56 \% žensk ni vedelo, $\checkmark$ primerjavi $z$ moškimi ( $44 \%$ ), ali je država $v$ proračunu namenila dovolj finančnih sredstev za priprave in predsedovanje naše države uniji.

Kadre, ki bodo delali in že delajo pri projektu predpriprav in aktivno $v$ času predsedovanja, je bilo treba dodatno izobraziti. Izobraževanje se je začelo $v$ drugi polovici leta 2005. 
Za priprave na predsedovanje in za njegovo izvajanje imajo organi državne uprave pravico do 310 dodatnih zaposlitev za določen čas. Vlada Republike Slovenije je 6. oktobra 2005 sprejela Kadrovski načrt za predsedovanje, na podlagi katerega so bili večinoma že izbrani kadri za izvedbo najpomembnejših nalog. Kadri so se izobraževali za delo doma in v Bruslju.

Preglednica 4: Odgovori na vprašanje: Kadri, ki jih je treba zagotoviti v času pred in med predsedovanjem, se dodatno izobražujejo. Ali menite, da je to izobraževanje dovolj dolgo in kakovostno?

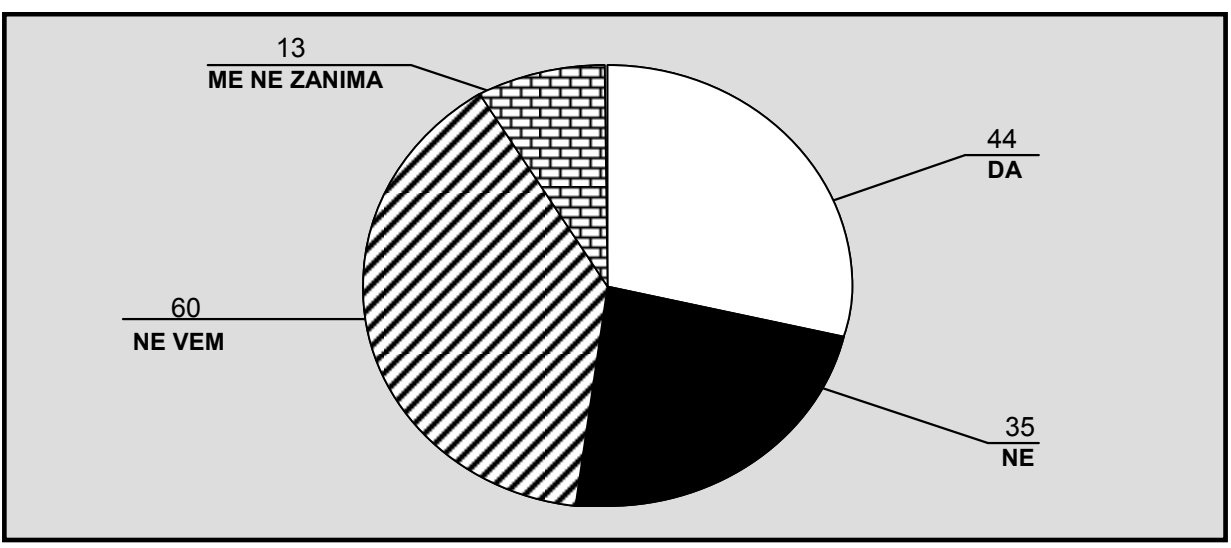

$\checkmark$ projektu sodelujeta dve osnovni skupini kadrov, kadri na vsebinskih nalogah predsedovanja $\vee$ Bruslju in $\vee$ Ljubljani ter kadri, ki organizacijsko zagotavljajo izvedbo predsedovanja (Bagon, 2006, str. 1).

$\mathrm{Na}$ začetku je bilo treba ugotoviti, kakšne vrste nalog je treba opraviti, kakšne kadre je treba imeti ter izpeljati nabor kandidatov za nosilce vseh nalog. Ključnega pomena je vsekakor pravilno programirano usposabljanje kadrov za predsedovanje (Bagon, 2006, str. 1).

Od sodelujočih anketirancev je na zastavljeno vprašanje odgovorilo 60 anketirancev, da ne vedo, kako dolgo poteka izobraževanje kadrov za potrebe predsedovanje Slovenije Evropski uniji in ali je to izobraževanje kakovostno. 44 anketirancev je menilo, da je izobraževanje dovolj dolgo in kakovostno, 35 pa se jih je izreklo, da to izobraževanje ni dovolj dolgo in kakovostno. 13 ljudi pa to ni zanimalo.

Kako uspešno bo država predsedovala, je odvisno od njenih priprav. Predsedstvo pripravlja, sklicuje in vodi sestanke Sveta Evropske unije na vseh ravneh, od delovnih skupin do zasedanj Sveta ministrov in Evropskega sveta. 
Marija Minka Jerebič

Priprave na predsedovanje Slovenije Evropski uniji

Nadalje organizira že vnaprej dogovorjena vrhunska srečanja Evropske unije s tretjimi državami. Za pripravo in uspešno vodenje velikega števila formalnih zasedanj mora predsedujoča država opraviti tudi veliko neformalnih zadev (Bagon, 2006, str. 1).

Anketirancem je bilo zastavljeno tudi vprašanje, kaj menijo o uspešnosti predsedovanja.

$42 \%$ anketirancev je odgovorilo, da bo Slovenija uspešno predsedovala uniji, $9 \%$ pa o tem ni imela nikakršnega dvoma. Kar $39 \%$ anketirancev je menila, da bo Sloveniji omenjeni projekt uspel do neke mere. $5 \%$ anketirancev je menilo, da naši državi omenjeni projekt ne bo uspel, ravno toliko se jih je izreklo, da ne ve, ali bo projekt uspel ali ne.

\section{Preglednica 5: Odgovori na vprašanje: Ali menite, da bo Slovenija uspešno predsedovala Evropski uniji?}

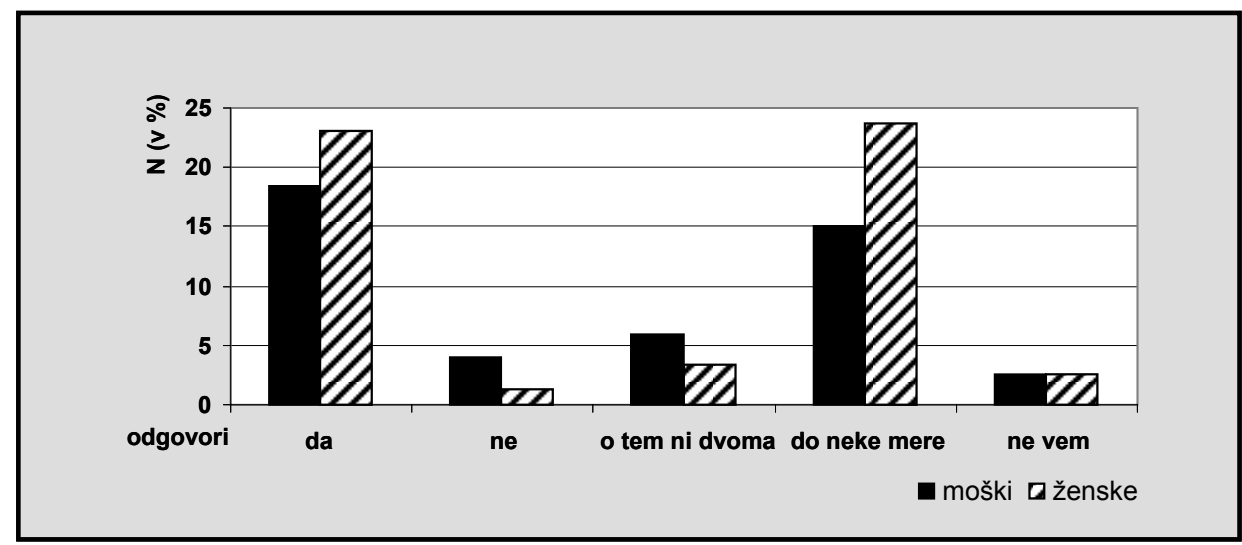

Zanimiva je primerjava med spoloma glede tega odgovora. Kar $23 \%$ žensk je odgovorilo pritrdilno, da bo Slovenija uspešno predsedovala uniji in prav tolikšen odstotek žensk je bil mnenja, da do neke mere. Na eni strani prepričanje $\vee$ uspeh, na drugi strani dvom, pri drugih odgovorih ženske niso prav posebno izstopale, morda le pri odgovoru, da Sloveniji ne bo uspelo predsedovanje, saj jih je negativno odgovorilo le $1.3 \%$ v primerjavi z moškimi $(3,9$ $\%)$. Manjši je bil tudi odstotek pri odgovoru, da o tem ni dvoma, da Sloveniji ne bi uspelo predsedovanje, med odgovori med ženskami in moškimi. Ženske so odgovorile na to vprašanje s 3,2 \%, moški pa s 5,9 \%. Pri zadnjem možnem odgovoru, kjer so se anketiranci opredelili, da ne vedo, ali bo Slovenija uspešno predsedovala ali ne, je bil odstotek odgovorov med spoloma enak (2,6 \%). 


\subsubsection{Prepoznavnost Slovenije v svetu}

Predsedovanje je izjemna priložnost za promocijo Slovenije, slovenske kulture ter tradicije in za utrditev njene prepoznavnosti v Evropi in svetu. Slovenija že načrtuje organizacijo številnih kulturnih dogodkov doma in v tujini, na katerih bodo sodelovali najbolj uveljavljeni slovenski umetniki. Tudi celostna grafična podoba je že bila izbrana, po tradiciji bo javnosti predstavljena le nekaj mesecev pred začetkom predsedovanja.

Preglednica 6: Odgovori na vprašanje: Ali bo Slovenija uspela izkoristitit svojo prepoznavnost $v$ svetu $v$ času predsedovanja?

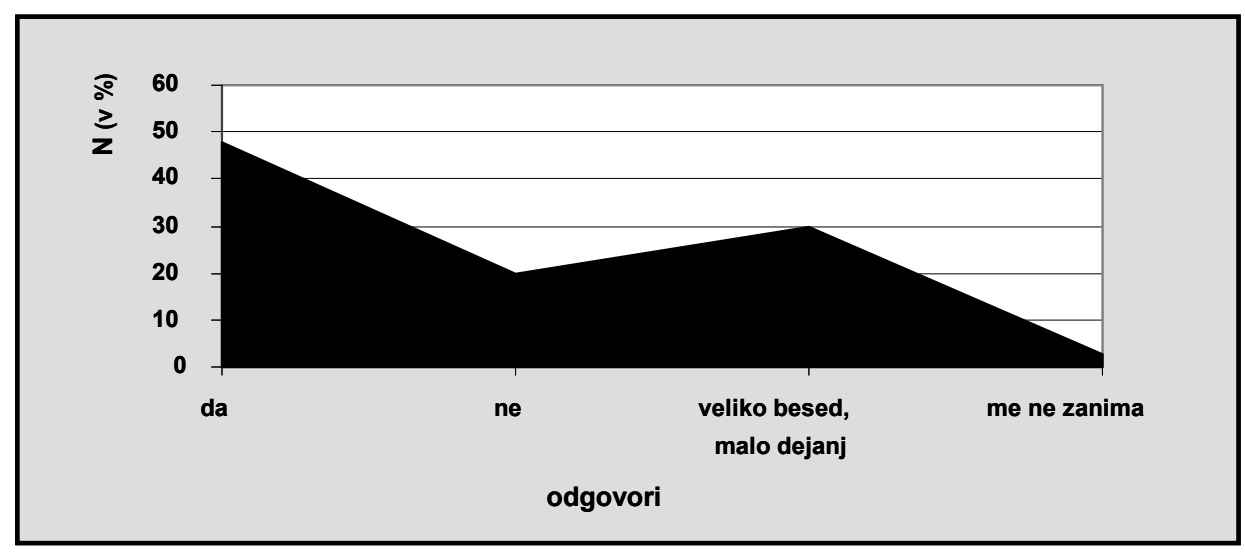

Anketiranci so bili vprašani, ali bo državi uspelo še bolj izkoristiti svojo prepoznavnost $\vee$ času predsedovanja. Na zastavljeno vprašanje so odgovorili pritrdilno. Kar 48 \% anketirancev meni, da bo Republika Slovenija znala izkoristiti svojo prepoznavnost $\vee$ svetu še bolj $\vee$ času predsedovanja, medtem ko jih je 19,7 \% anketirancev odgovorilo negativno. Veliko odstotek anketirancev se je opredelilo za tretji možni odgovor, ki je podal možnost "veliko besed, malo dejanj", saj ga je obkrožilo kar 29,6 odstotkov. Le 2,6 odstotkov anketirancev pa ta tema ni zanimala. Pri primerjavi odgovorov med moškimi in ženskami na zastavljeno vprašanje o prepoznavnosti Slovenije v svetu v času predsedovanje uniji ni bilo bistvenih razlik. Največja razlika med spoloma se je pokazala pri drugem odgovoru, kjer so anketiranci odgovorili, da Sloveniji ne bo uspela prepoznavnost $v$ svetu, ko je 66,7 \% žensk odgovorilo negativno $v$ primerjavi z moškimi (33,3 \%). 
Marija Minka Jerebič

\section{Priprave na predsedovanje Slovenije Evropski uniji}

\section{Sklepne ugotovitve}

Priprave na predsedovanje Slovenije Evropski uniji so v polnem teku. Potekajo zelo intenzivno in uspehi se kažejo že na mnogih področjih.

Slovenija je pri pripravi 18-mesečnega programa predsedujočega tria $v$ sodelovanju z obema državama oblikovala dolgoročnejšo perspektivo za delo Evropske unije, kot je bilo $v$ navadi do sedaj, saj so bile upoštevane skupne prioritete vseh treh držav.

Pričujoče raziskovalno delo nudi kratek pregled priprav Slovenije na predsedovanje, delo $\vee$ ožjih in širših delovnih skupinah, predvsem pa predstavi najpomembnejše teme, ki jih je naša država zavzela za prioritete $\vee$ času predsedovanja.

Namen izvedenega raziskovalnega dela je bil predstaviti, kako državljani Slovenije spremljajo predpriprave na predsedovanje, koliko so o tem obveščeni in kakšen izziv predstavlja predsedovanje za prebivalce.

$\mathrm{Na}$ anketo se je odzvalo 61 odstotkov vseh povabljenih. Po rezultatih sodeč Slovenci dobro spremljajo dogajanje na področju predpriprav Slovenije na predsedovanje Evropski uniji.

Slabše poznavanje anketirancev je na področju vsebine, financ in kadrov. Medtem ko večina meni, da bo Sloveniji predsedovanje popolnoma uspelo in se bo, s tem posledično, tudi prepoznavnost $v$ svetu močno dvignila.

Republika Slovenija je $v$ pripravah za predsedovanje zagotovo dosegla visoko stopnjo informiranosti državljanov, saj to potrjujejo odgovori $\vee$ pričajoči anketi. Do predsedovanja je še pol leta in nedvomno bodo priprave na predsedovanje dosegle cilj, ki si ga je država v začetku predpriprav zastavila.

Marija Minka Jerebič je specialistično delo s področja javne uprave zagovarjala na Fakulteti za upravo Univerze v Ljubljani leta 2006. Na Ministrstvu za kulturo Republike Slovenije je zaposlena kot svetovalka $v$ kabinetu za izvajanje in organizacijo protokolarnih dejavnosti doma in $v$ tujini ter poleg tega dela opravlja tudi dela tajnice ministra. Na Fakulteti za upravo končuje magistrski študij. 
Marija Minka Jerebič

Priprave na predsedovanje Slovenije Evropski uniji

\section{Literatura in viri}

- $\quad$ Bagon, J.(2006):Kadri za predsedovanje Slovenije EU v letu 2008. V: Devjak, Srečko (ur.): Zbornik XIII. Dnevi slovenske uprave 2006, Fakulteta za upravo, Ljubljana.

- Government of the Republic of Slovenia (2006): Survey of inherited agenda for the period of Slovenia's Presidency (January - June 2008). Ljubljana.

- $\quad$ http://www.svez.gov.si/

- Lenarčič, J.(2006): Predsedovanje EU - izziv in priložnost za slovensko upravo. V: Devjak, Srečko (ur.): Zbornik XIII. Dnevi slovenske uprave 2006, Fakulteta za upravo, Ljubljana.

- Lenarčič, J.(2005): Priprave Slovenije na predsedovanje Evropski uniji Organizacijska struktura za pripravo in izvedbo predsedovanja, povzetki projektnih nalog, priprave ministrstev na predsedovanje in okvirna časovnica za izvedbo priprav. Služba Vlade Republike Slovenije za evropske zadeve, Ljubljana.

- Maastrichtska Pogodba o Evropski uniji s celotnim besedilom Pogodbe o ustanovitvi Evropske skupnosti podpisana v Maastrichtu 7. februarja 1992. Uradni list Evropske unije 92/C 224/01, Bruselj, 1992.

- $\quad$ Svet Evropske unije ( 2006): 18-mesečni program predsedovanja Nemčije, Portugalske in Slovenije. SN 4294/2/06 REV 2, Bruselj.

- Svet Evropske unije (2006): Poslovnik Sveta Evropske unije. Uradni list Evropske unije, L 285/47, (2006/683/ES, EURATOM), Bruselj. 
Marija Minka Jerebič

Priprave na predsedovanje Slovenije Evropski uniji

\section{SUMMARY}

\section{PREPARATIONS FOR THE PRESIDENCY OF SLOVENIA OF THE EUROPEAN UNION}

Soon after the adhesion of Slovenia to the European Union, during the month of December, after the session of the Council of the European Union, it was agreed upon that Slovenia would be the first one among the new member states to assume presidency of the Union.

For Slovenia this represents a great challenge, duty and responsibility, as the Presidency of the European Union and the European Council is not only a project in the field of European affairs, but also a project of national significance which will contribute to the reputation of the country among member states of the European Union and in the world as well.

The Presidency of the Council of the European Union and the European Council is by its organizational structure and disposition of financial sources an extremely demanding national project requesting the cooperation of a large number of people.

For a successful presidency it is important to observe the principle of neutrality and impartiality. The objective of the presidency is to achieve progress at the work of the Union. Adapted to this objective is also the method of work marked above all by searching for compromise solutions among 27 member states that simultaneously take into account the positions of the European Commission and the European Parliament. In leading of discussions the chairman tries to abstain from giving preference to partial interests but he just the same keeps the so called "power of the chair" because he convenes sessions, proposes agenda, leads the sessions and proposes conclusions.

A successful performance of the presidency represents an extremely intensified extent of preparation in the capital of the presiding country and in the Permanent Representation of the country in Brussels. The country must prepare and qualify its entire administration. By doing this, it must adapt the working methods to its tradition and culture; the method of organizing and operating also depends on the size of the country and its interests. Assistance of the Secretariat General of the Council of the European Union is provided to the presiding country. 
On January the $6^{\text {th }} 2005$ the Government of the Republic of Slovenia by a special decision appointed a Select task force for the preparations of the Presidency of the European Union. The Select task force is to make sure that the project of the Slovene Presidency of the European Union is led consistently, to lay down general political guidelines and priorities and to monitor the course of preparations of the presidency within the state administration.

For operative leading of preparation and carrying out of the presidency project and for coordination, direction and monitoring of the work of all participants in this project the Select task force appointed a larger Task force for the Presidency. This task force, led by State Secretary for European Affairs, includes the representatives of line ministries and other agencies. The task force coordinates, directs and monitors the work of individual sub-groups, ministries and other agencies, included in the preparation of the Presidency.

As support to the larger Task force a special Project group for coordination of preparations and Slovenia's Presidency of the European Union was set up in the Government Office of the Republic of Slovenia for European Affairs. It was established as a support to the presidency and preparations related to it, as well as a contact point of Slovenia for communication with the two co-presiding countries.

During its first session the Select task force identified five basic groups of tasks which are to be carried out within the preparations for the presidency. For the execution of separate group tasks five sub-groups were set up within the larger Task force: Sub-group for program of the presidency, Sub-group for permanent officials, Sub-group for public relations and promotion, Sub-group for logistic organization of the presidency and Sub-group for the budget of the presidency. Further on the Select task force determined the supporting agencies for the execution of separate tasks and sub-group leaders. State agencies, competent for carrying out separate tasks cooperate within the sub-groups with their representatives. When needed other line ministries are also included in their work.

Citizens are very well informed about the ongoing preparations. The information is not so good concerning contents, finances and cooperating officials, which is obviously not of interest for citizens, because they have confidence in the work of the government. 